\title{
American Library Association Annual Conference 2016
}

IRENA TREBIC

University of British Columbia, Vancouver, British Columbia, Canada

\section{American Library Association Annual Conference 2016 \\ Orlando, FL \\ J une 23-28, 2016 \\ http://2016.alaannual.org/}

\section{Overview}

More than 16,000 library and information professionals explored the changing role of libraries at this year's American Library Association (ALA) conference, themed "Libraries Transform". ALA hosted its 135th Annual Conference and Exhibition in Orlando, Florida, June 23-28, 2016. Participants representing a wide range of libraries from more than 40 countries engaged with 500 sessions and explored 900 exhibitors.

Renowned American academic, author, and radio host Michael Eric Dyson served as the keynote speaker at the opening general session. Other featured speakers included award-winning Canadian author Margaret Atwood, New York Times bestselling author Brad Meltzer, and American actress and advocate for immigration reform Diane Guerrero. Award-winning actress and New York Times bestselling children's author Jamie Lee Curtis was the closing general session speaker.

Business librarians and information professionals at the conference were offered a great deal of opportunity to network and share ideas at the conference. Many of the sessions of interest to business librarians were sponsored by Business Reference and Services Section (BRASS) of the ALA Reference and User Services Association (RUSA) division. The rich BRASS programming made this conference especially relevant to academic business librarians, providing a balance between formal learning opportunities and social events and gatherings. The focus of this conference report will be the presentations of interest to business and social science librarians.

\section{BRASS Pre-Conference: Business Data for Librarians}

This full-day workshop was packed with information and tools that attendees could use at their own institutions. Three speakers separately spoke about data in libraries, financial data, and marketing data. The preconference finished off with a discussion about business data.

In the first session, Bobray Bordelon from Princeton University reviewed statistical terms and spoke about interpreting survey documentation. This was followed by an overview of various statistical tools, databases, and other online data collections, some of which may be accessed free of charge and others that are subscription-only. There was a hands-on team exercise using the United States Census Bureau Current Population Survey to find data.

Todd Hines, also from Princeton University, focused on financial data in the second session. He provided an overview of 
the main topics in finance and covered some primary resources. This session was particularly useful for new business librarians as it compared different financial databases and the types of information (such as stocks or analyst reports) they contain.

In the third session of the pre-conference, Andy Spackman from Brigham Young University concentrated on data sources for marketing. In this interactive workshop, attendees had time to explore tools such as the American Time Use Survey, which measures the amount of time people spend doing various activities such as paid work, childcare, volunteering, and socializing, and the Consumer Expenditure Survey, which provides information on the buying habits of American consumers. Both of these resources are available through the Bureau of Labor Statistics.

\section{BRASS Academic Forum: I nnovation and Risk Taking}

This 90 minute forum consisted of seven short presentations which gave the speakers a chance to provide a quick overview of their innovative and risk-taking efforts. The presentations featured novel services and pilot projects among business academic librarians from different universities across the United States. Participants had a bit of time to ask questions and discuss the reasons behind the successes or failures of these endeavors. Some of the ideas covered are discussed below.

Jonathan Torres from University of Arkansas Libraries described a reading initiative called the Walton Reader's Spotlight, where a business librarian interviewed business faculty and staff about books that have inspired them. Meant to "promote intellectual growth and empowerment through literature"
("Libraries and Walton College Team Up", 2016) at the University of Arkansas, the program encouraged readers to talk about books that intrigue them. Partnerships with faculty and the business writing center were formed as a result, and the number of reference sessions increased. This was also an excellent alternative for library outreach to online students.

Raymond Pun and Hiromi Kubo from California State University at Fresno touched upon reference to language-learning software (such as Mango Languages) in their research workshops. Learning foreign languages is relevant to both international students as well as local business students who are interested in participating in international case competitions or conducting business abroad. These librarians also participated in entrepreneurship initiatives by mentoring high-school students on their business ideas and projects. They also served as guest speakers and judges for classroom business plan competitions.

C.J. Ivory and Missy Murphey, from University of Central Florida, spoke about engaging students during one-shot instruction sessions in a capstone course. One of the goals of this workshop was to help students build presentation skills. Students formed teams that were each responsible for presenting a database. An interesting takeaway of this session was that students were unwilling to critique each other's presentations.

In another lightning talk, Jordan Nielsen from San Diego State University Library demonstrated how to set up an account with Youcanbook.me, a free automated scheduling tool, to schedule student appointments. The tool enables a librarian to set the hours available each week and to customize the length of bookable appointments. The 
software sends e-mails to confirm the appointments to both the librarian and to the student. This tool was received very positively by students; the majority of library consultations are currently scheduled via the booking form.

The variety of content and ideas made this session useful to business librarians. Although the presentations were very brief, attendees learned about the impacts and outcomes of various new ventures coming from different areas of business librarianship including instruction, reference, collections, and outreach.

\section{BRASS Discussion Group}

On the fourth day of the conference, BRASS members met for a discussion of current issues relevant to the field of business librarianship. In open-mic format, members debated, among other topics, the restriction of access to resources under certain circumstances, the need for more resources on newer industries such as medical cannabis production, and the relationship between academic and public libraries.

Restricting access to resources was discussed at length in this session. Attendees addressed questions about what to do if a professor's research turns into something commercial or if a student shares full reports with clients. Academic versions of many databases are offered at discounts and are not to be used for commercial projects. Ensuring that use of library resources does not infringe on license agreements is an important concern to academic business librarians. Attendees discussed such strategies as contacting vendors to learn about extent of use, speaking with the university legal team for guidance, and explaining to students that they cannot provide their experiential learning clients with entire reports.

Finding resources for craft brewing and cannabis production was also discussed. Several attendees referenced their work at institutions with beer brewing programs; others have assisted students find reports using library databases for projects related to the commercialization of marijuana. Also mentioned was the topic of medical industry resources, where several tools for drug pricing rates, hospital activities, and health statistics were shared with the audience.

Several speakers provided advice for strengthening relationships between public and academic libraries. Interesting ideas included reaching out to public librarians for informal meetings and letting students and alumni know about the excellent resources available to them at local public libraries. Business librarianship groups whose members include librarians working at public, academic, and special libraries have also been formed in certain States. One such example is the Business Librarianship in North Carolina (BLINC) group.

Overall, this discussion group was an excellent opportunity for librarians to share resources and obtain ideas from colleagues, in addition to discussing issues that frequently arise in an academic business setting.

\section{New Business Librarians Discussion Group}

Networking is an excellent strategy for developing a competitive edge in our field as discussed in Bobray Bordelon's 2008 article, "Networking Strategies for Business and Economics Librarians" (p. 372). The new business librarians' discussion group provided an opportunity to network with those new to the field. The first portion of the session was 
dedicated to introductions and chat with members seated around each table. In the second portion of the session, members were engaged with open questions and were invited to come up to the microphone and ask a question to the audience. This format allowed for discussion and served as a platform for making connections with other librarians.

Some of the discussion topics included personal professional development, finding creative ways to reach out to students and faculty, and getting up to speed with business information. This last topic was particularly relevant as the majority of the 31 librarians in attendance did not have an undergraduate degree in a business-related discipline.

Overall, this discussion group was a fantastic means of networking with fellow newbie business librarians and learning about their institutions and approaches to transforming librarianship.

\section{Student Privacy: The Big Picture on Big Data}

Rapidly evolving technology capacitates the collection and analysis of ever increasing types and volumes of data about students' performance and behavior, including their use of library resources. In her 2016 article, "Student Privacy in the Age of Big Data," Ann Dutton Ewbank states that librarians "serve as stewards of privacy and educate the scholarly community about its tenets" (p. 6). She argues that the role of librarians is to safeguard student privacy as well as to educate the scholarly community about the impacts of new technologies on student privacy.

This ALA session on student privacy in the age of big data was an eye opener for both school librarians as well as academic librarians. Elana Zeide, a fellow at New York University's
Information Law Institute, voiced deep concerns about individual privacy and data security, especially as schools increasingly adopt vendor-based data services that require the transfer of student data to third-party providers. The session alluded to the idea that students, like people in general do not like their information to be collected for one purpose and then used for another purpose. Elana Zeide emphasized the importance of thinking critically about the purpose of collecting data and considering some potential unintended consequences before proceeding with data collection. She advocated for transparency about how the data will be used. One suggestion included erasing records after a certain period of time.

The attendees were briefed on legislation being passed about privacy such as California's Student Online Personal Information Protection Act ( $\underline{\text { SOPIPA) }}$, and the "right to be forgotten" in Europe, a challenge that Google has been fighting for a few years. Citizens of the European Union can exercise their "right to be forgotten" by requesting that search engines erase links to information about them that they themselves consider "prejudicial" (Youm and Park, 2016, p. 273).

One remarkable example concerned the use of RFID chips to track student whereabouts in certain public schools in the United States. Several students were shocked to receive phone calls from advisors about their lunchtime eating habits. The students were not aware their data would be used to track how often they ate in the school cafeteria, or that it would be shared with advisors. Overall, this session was very informative and thought-provoking. 


\section{Informal Social Events}

In addition to excellent sessions, BRASS provided a number of informal events that offered attendees an opportunity to network with other business librarians. The RUSA BRASS member reception was a fun way to end the second day of the conference. The reception took place at the cozy Cuba Libre Restaurant. Attendees were welcomed by Chad Boeninger (Ohio University), Chair of BRASS Publications and Communications Committee. This social event was an outstanding venue for networking with colleagues and meeting new BRASS members from other institutions.

BRASS also organized a dinner buffet for its members at Cafe Gauguin. This was a terrific opportunity to engage in stimulating conversation with other business librarians and to relax after a busy conference.

\section{Conclusion}

The ALA 2016 Annual Conference provided a myriad of different viewpoints on the transformation of libraries, librarianship in general, and business academic librarianship specifically. There were plenty of opportunities for serendipitous learning and discovery, both individual and shared. The peer support of so many business librarians in one place, eager to share and collaborate was wonderful to experience. The variety of content and meetings made this conference beneficial to both seasoned business librarians and those just starting out in the field.

\section{References}

Bordelon, B. (2008). Networking strategies for business and economics librarians. Journal of Business \& Finance Librarianship, 13(3), 371377. doi:10.1080/08963560802183294
Ewbank, A. D. (2016). Student privacy in the age of big data. Knowledge Quest, 44(4), 6.

Libraries and Walton College Team Up for Popular Reading Initiative. (2016, February 3). University of Arkansas news. Retrieved from http://news.uark.edu/articles/33487/librariesand-walton-college-team-up-for-popularreading-initiative

Mackay, M. (2016). 2016 ALA Annual Conference \& Exhibition-Libraries Transform, and We Stand With Orlando [Press release]. American Library Association. Retrieved from http://www.ala.org/news/pressreleases/2016/06/2016-ala-annual-conferenceexhibition-libraries-transform-and-we-stand

Youm, K., \& Park, A. (2016). The "right to be forgotten" in European Union Law: Data protection balanced with free speech? Journalism \& Mass Communication Quarterly, 93(2), 273-295. doi:10.1177/1077699016628824

135th Annual Conference and Exhibition Program and Exhibit Directory. (2016). American Library Association. Retrieved from http://2016.alaannual.org/sites/default/files/A C16_ProgramBook_part1of3.pdf 